\title{
A KISVÁROSI FÖISKOLÁK HALLGATÓINAK TÁRSADALMI HELYZETE ÉS ÉLETMÓDJA
}

\section{(Social Status and Lifestyle of Small Town College Students)}

\section{PETRÁS EDE}

Kulcsszavak:

kisvárosiföiskolák föiskolai hallgatók agrár-felsőoktatás pedagógusképzés

A tanulmány négy kisvárosi foisskolai kar hallgatóinak társadalmi összetételét, motivációit, lakóhelyét, mindennapi életét és jövőterveit mutatja be egy kérdöives vizsgálat eredményei alapján. Megállapitja, hogy minden intézmény egy sajátos, a többitöl lényegében eltérö helyzetủ és életvitelü hallgatói körrel rendelkezik. Az azonos városban müködö két kar hallgatóinak összehasonlitásából arra lehet következtetni, hogy a kisvárosok csak a hallgatók mindennapi életére képesek komolyabb hatást gyakorolni, mig a jövöre vonatkozó terveik és lehetőségeik elsősorban az oktatási intézményektöl függenek.

\section{Bevezetés}

Felsőoktatási intézményeink sajátos csoportját alkotják a kisvárosi föiskolák. Hallgatóik élete számos ponton eltér a nagy egyetemek diákságának mindennapjaitól. Tanulmányaikat és majdani karrierjüket meghatározza az a tény, hogy a kisvárosi fỏiskolák általában gyakorlat-orientált alkalmazott szakembereket, középszintủ vezetőket nevelnek. Szabad idejük és kulturális életük helyszíne pedig kisvárosi település, az ebben rejlö minden lehetőséggel és korláttal együtt.

2006 novemberében három városban négy kar diákjainak véleményét kérdeztük meg mindennapi életükröl, föiskolájukról és annak városáról. Az adatgyüjtés során karonként átlagosan 57 hallgató töltött ki kérdőivet. A kérdőivek adatait karonként hat-hat rövid, tematikus interjúval egészítettük ki, melyeket a hallgatókkal mindennapi kapcsolatban álló oktatókkal készítettünk el.

A tanulmányban elemzett hallgatók Hódmezővásárhelyen a Szegedi Tudományegyetem Mezőgazdasági Kara (SZTE-MGK), Nagykőrösön a Károli Gáspár Református Egyetem Tanítóképzö Föiskolai Kara (KRE-TFK), Szarvason pedig a Tessedik Sámuel Főiskola Pedagógiai Főiskolai Kara (TSF-PFK), ill. Mezőgazdasági Víz- és Környezetgazdálkodási Főiskolai Kara (TSF-MVK) diákjai.

\section{A karok képzési kinálata}

Az intézmények képzési profilja viszonylag tiszta, mindegyik föiskola rendelkezik egy-két jellemzö, országosan ismert és elismert szakkal (1. táblázat). 


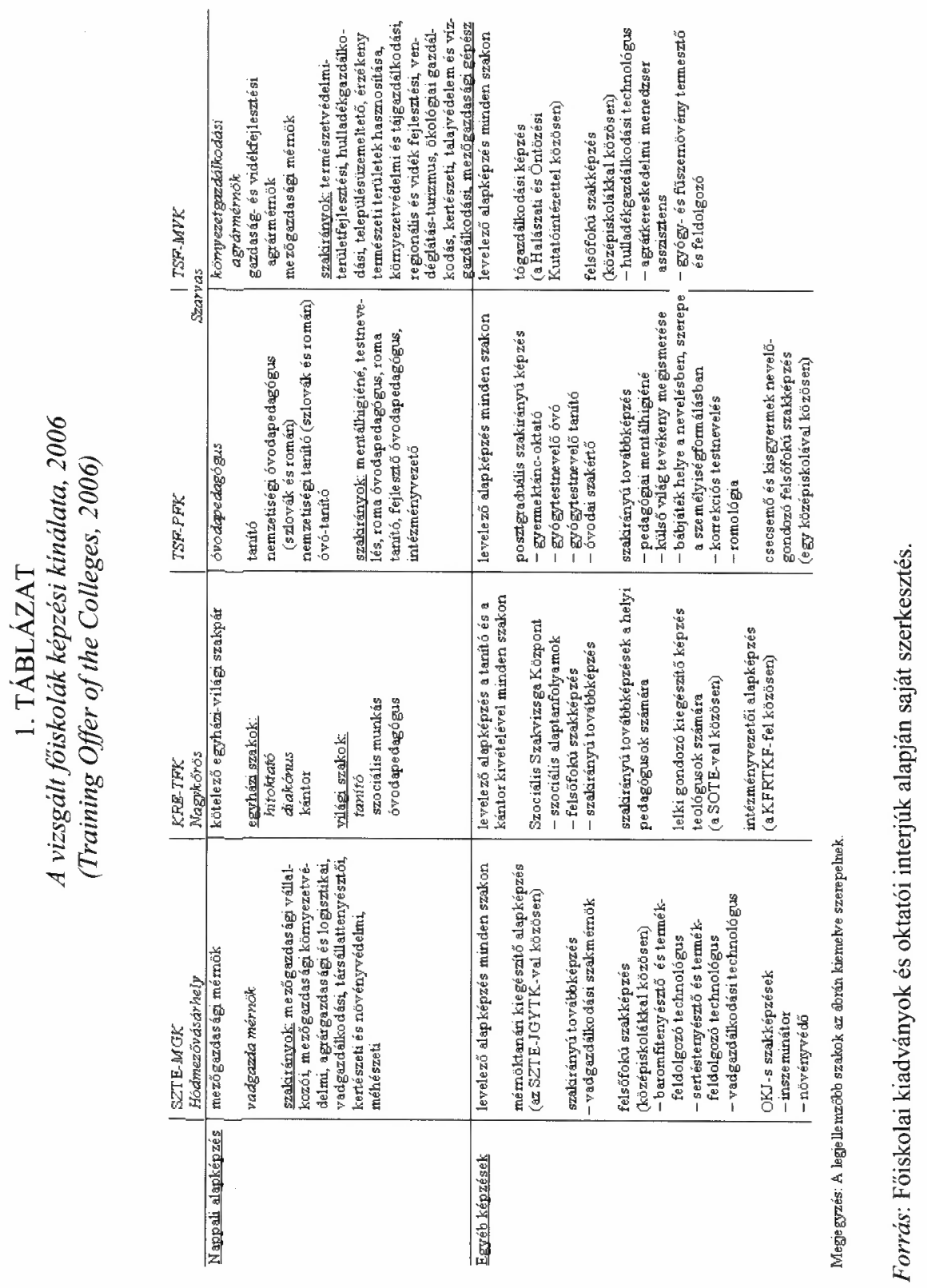


Petrás Ede : A kisvárosi főiskolák hallgatóinak társadalmi helyzete és életmódja .

Tér és Társadalom 21. évf. 2007/4. 111-129. p.

Ilyenek Vásárhelyen az agrármérnök és a napjainkra szakká fejlődött vadgazda szakirány, Nagykőrösön a református tanitó-hitoktató és a diakónus-szociális munkás szakpár, a szarvasi karokon pedig az óvodapedagógus, illetve a környezetgazdálkodási képzés.

Jellemzö az útkeresés, a meglévőkhöz valamilyen mértékben kapcsolódó új szakokkal való kísérletezés. A kilencvenes évek végétöl dominánssá vált regionális együttmüködések rovására a legutóbbi években újra növekedni kezdett a távoli intézményekkel kiépített kapcsolatok jelentősége. A karok képzési kínálatában a fóiskolai szintủ nappali és levelező alapképzésen túl mára megtalálhatóak a távoktatásos képzések, a föiskolai szakirányú továbbképzések, illetve a felsőfokú szakképzés és a szaktanfolyamok is.

\section{A hallgatók száma}

Bár mindegyik vizsgált intézmény a kisvárosi föiskolák közé tartozik, méretüket tekintve mégis jelentősen eltérnek egymástól. Míg 2005-ben a két szarvasi karra összesen több mint ezer nappali tagozatos hallgató járt, és a levelezỏ, újabb diplomás, szakirányú továbbképzéses és egyéb nem nappali tagozatos hallgatók létszáma egyenként is meghaladta az ezer föt, addig a vásárhelyi föiskolának összesen 728 , a nagykőrösi karnak pedig mintegy 550 hallgatója volt (nem számítva a marosvásárhelyi kihelyezett tagozat $\mathrm{kb} .200$ hallgatóját). A két pedagógiai karon létszámában a levelezó tagozatos (és egyéb nem nappali) képzés dominál, különösen a nagykőrösi fóiskolán, ahol a nappali tagozatosok aránya alig haladja meg a 20\%-ot. A mezőgazdasági karokon ez az arány jóval magasabb, Vásárhelyen közelíti az 50\%-ot, a szarvasi agráros hallgatóknak pedig csaknem kétharmada nappali tagozatos (1. ábra).

\section{1. ÁBRA}

A hallgatók létszáma (a KRE-TFK marosvásárhelyi kihelyezett tagozata nélkül), 2005 (Number of Students, 2005)

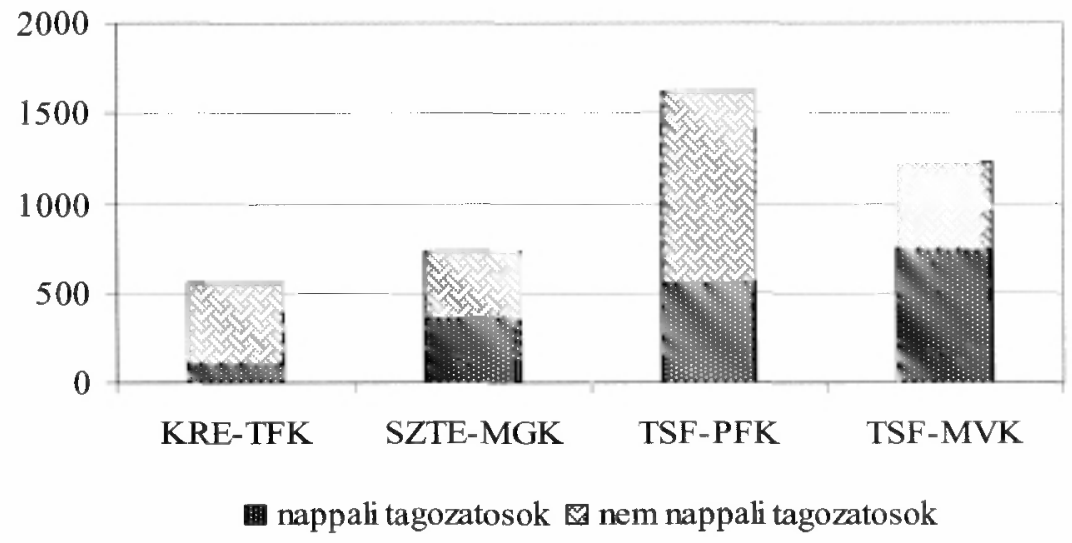

Forrás: Főiskolai kiadványok és oktatói interjúk alapján saját szerkesztés. 
Petrás Ede : A kisvárosi főiskolák hallgatóinak társadalmi helyzete és életmódja .

Tér és Társadalom 21. évf. 2007/4. 111-129. p.

A vásárhelyi intézményben 1990 óta nagyjából állandó a hallgatók létszáma, évente mintegy 200 nappali és levelező tagozatos hallgató kezdi meg tanulmányait. A nappalisok létszáma Nagykőrösön is nagyjából változatlan ebben az időszakban, évente mintegy 30 fö. A levelezősöké viszont a fokozatosan bővülö képzési kínálat következtében évröl évre emelkedett. A nappali tagozat alacsony létszáma annak is köszönhetö, hogy a kar mindeddig igen erős minőségi szürést alkalmazott a felvételi eljárás során.

A szarvasi pedagógiai kar hallgatói létszáma a kilencvenes évek közepének felfutása után (mely föleg a kihelyezett tagozatoknak volt köszönhető) mára stabilizálódott, évente mintegy 150 hallgató kezdi meg tanulmányait, akiknek többsége óvópedagógus szakos. Ezzel szemben a mezögazdasági kar - a kilencvenes évek mélyrepülése után - az utóbbi néhány évben élte meg hallgatói létszámának gyors emelkedését.

\section{A hallgatók lakóhelye}

Beiskolázási területe alapján a nagykőrösi föiskola erősen különbözik a másik három kartól. Hallgatói Magyarország és Kárpátalja szinte minden, reformátusok lakta vidékéről érkeznek, Nagykörösröl ugyanakkor évenként csupán 1-2 hallgató kezdi meg tanulmányait. A kérdőíves vizsgálat során megkérdezett diákok mintegy harmadrésze Pest megyében vagy Budapesten, egy másik harmaduk a Dunántúlon lakik, a többiek közül pedig majdnem minden második Kárpátaljáról érkezett (2. ábra).

\section{2. ÁBRA}

A KRE-TFK nappali tagozatos hallgatóinak lakóhelye, 2006

(Residence of Full-Time Students at KRE-TFK, 2006)

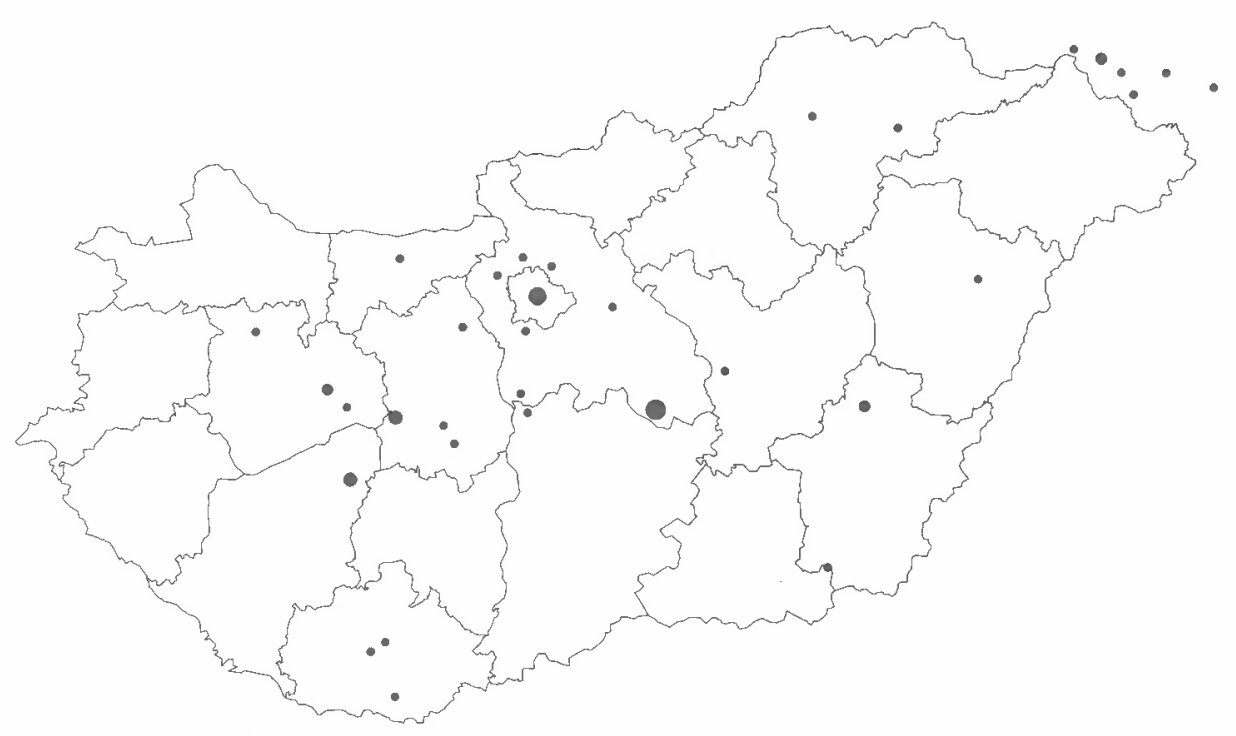

Forrás: Hallgatói kérdöívek alapján sajảt szerkesztés. 
A helybéli hallgatók alacsony arányának legföbb oka a föiskola és a képzés felekezeti jellege. Az egyházuk tanítása szerint vallásos emberek az országos helyzethez hasonlóan Nagykőrösön is csak egy kisebbségét alkotják a teljes lakosságnak, és természetesen a hívők közül is sokan választanak világi foglalkozást, így a legtöbb helyi fiatal számára a föiskola mint továbbtanulási lehetőség szóba sem kerül. Jól érzékelteti ezt az alábbi interjúrészlet:

„Mivel egyházi képző lett ez, a református egyház a fenntartója ennek a képzőnek, bizonyos kritériumokat is meghatároznak számunkra a nappali tagozatos képzésben. [...] Szakpárban müködnek a szakok, [...] egy civil vagy egy világi szak mellé egy egyházi szak kerül, és itt már belső elhivatottság alapján jönnek. Vannak nagykörösiek, vannak érdeklödök, de nem esik ez egybe. Aki most tanítói pályát választana vagy szociális pályát választana, azok nem ide jönnek elsősorban, hanem ha világi irányban van az elhivatottságuk, akkor elmennek vidéki főiskolákra. [...] A nappali tagozaton inkább a vidéki a jellemző, 95\%-ban, országos, sốt határon túli, tehát kárpát-medencei a beiskolázásunk." (oktatói interjú, KRE-TFK)

A levelező oktatás a föiskola méretéhez képest magas létszámú, s a nappali tagozatos képzésnél jóval szorosabb kapcsolatban áll a várossal és térségével. A világi szakokon számos nagykőrösi és környékbeli hallgató szerez alap- vagy másoddiplomát, a Szociális Szakvizsga Központ alaptanfolyamai és továbbképzései pedig regionális beiskolázással múködnek. Ezen a területen sokat jelent a föiskola közelsége és városszerte magas szakmai presztízse, melynek fó forrása a végzett hallgatók pozitív tapasztalata.

„Aki levelezőn szerzett diplomát, úgy fogalmaznék nagyon sarkosan, az azért Nagykőrösön szerzi meg, nem megy el Jászberénybe." (oktatói interjú, KRE-TFK)

„Az ő alma materi viszonylatuk, az erös. Lépten-nyomon találkozom, például tegnap egy lakógyúlésen fordultam meg, ahol valamikor idejáró, tizenéve itt végzett hallgató nagyon pozitívan nyilatkozott a fóiskoláról, plénum elött is említette, hogy mi mindent tanult itt. Tehát vannak ilyen kapcsolatok, akik itt vannak, elég jó képet mondanak rólunk." (oktatói interjú, KRE-TFK)

A nagykőrösi főiskolával ellentétben a többi intézmény elsősorban a szükebb térségéböl vonzza a fiatalokat. Különösen így van ez a vásárhelyi kar esetében, ahol igen magas a helyből, illetve a Csongrád megyéből érkezett hallgatók aránya (3. ábra). Ha pedig a 2006-os állapotot tükröző kérdőives mintát összevetjük a 2001 és 2005 között végzett hallgatók adataival, azt látjuk, hogy a Csongrád megyeiek aránya még az utóbbi néhány évben is folyamatosan nött, a korábban számos hallgatót kibocsátó tiszántúli megyékből pedig senki sem érkezett (4.ábra).

Jelenleg a föiskola hallgatóinak közel $90 \%$-a helyi vagy bejáró, a kollégisták száma pedig a korábbi évtizedekhez képest a töredékére csökkent. Különösen magas a helybéliek aránya, a kérdőíves vizsgálatunkban megkérdezett hallgatóknak több mint harmada lakik Vásárhelyen - ahonnan a korábbi évtizedekben nem sokan jelentkeztek a föiskolára. A levelező képzés beiskolázási területe viszont ennél jóval kiterjedtebb - ami elsősorban a vásárhelyi vadgazda képzés kurrens voltának és országos elismertségének köszönhető. 
Petrás Ede : A kisvárosi főiskolák hallgatóinak társadalmi helyzete és életmódja .

Tér és Társadalom 21. évf. 2007/4. 111-129. p.

\section{3. ÁBRA}

Az SZTE-MGK nappali tagozatos hallgatóinak lakóhelye, 2006

(Residence of Full-Time Students at SZTE-MGK, 2006)

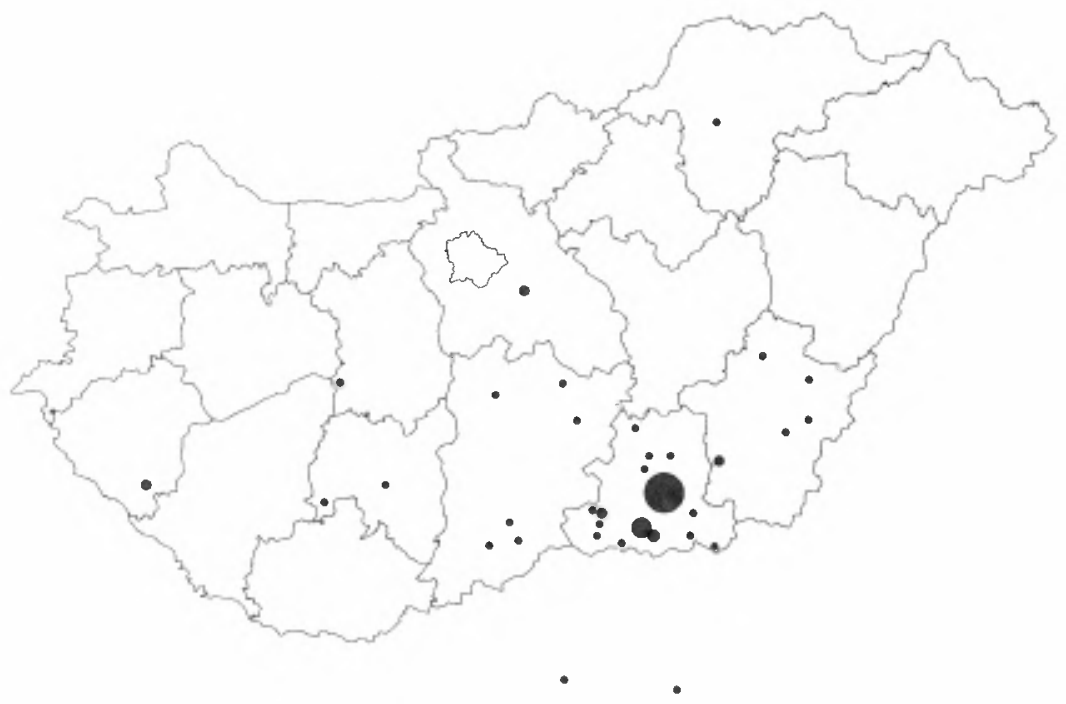

Forrảs: Hallgatói kérdőívek alapján saját szerkesztés.

\section{4. ÁBRA}

Az SZTE-MGK nappali tagozatos hallgatóinak lakóhelye megyék szerint, 2001-2005, $2006(\%)$

(Residence of Full-Time Students at SZTE-MGK by County, 2001 to 2005, and 2006)

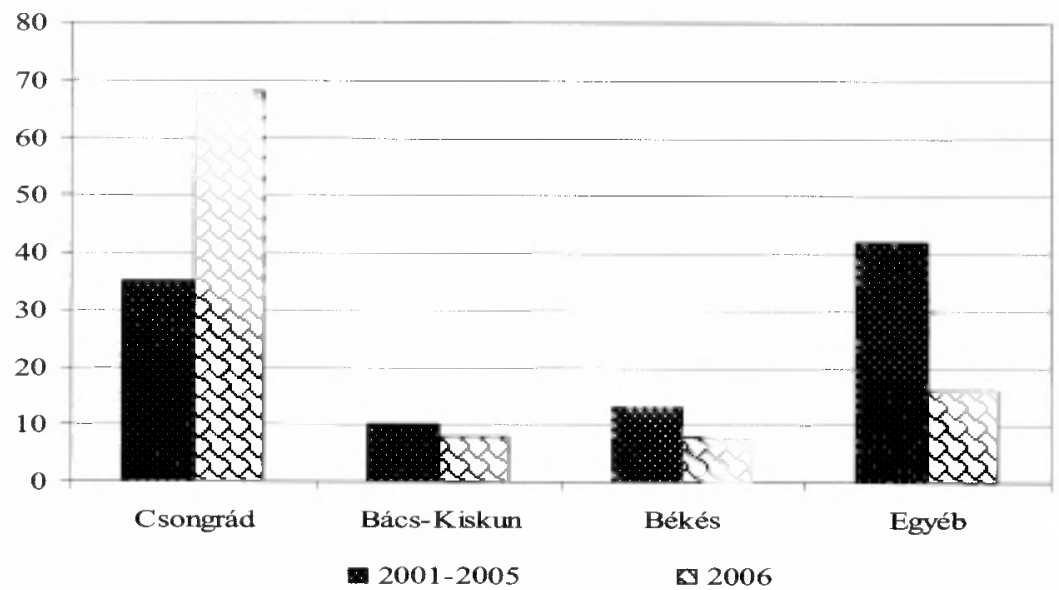

Forrás: Kis (2006), illetve hallgatói kérdöívek alapján saját szerkesztés. 
Petrás Ede : A kisvárosi főiskolák hallgatóinak társadalmi helyzete és életmódja .

Tér és Társadalom 21. évf. 2007/4. 111-129. p.

TÉT XXI. évf. 2007 — 4

Gyors ténykép

117

\section{5. ÁBRA}

A TSF-PFK nappali tagozatos hallgatóinak lakóhelye, 2006

(Residence of Full-Time Students at TSF-PFK, 2006)

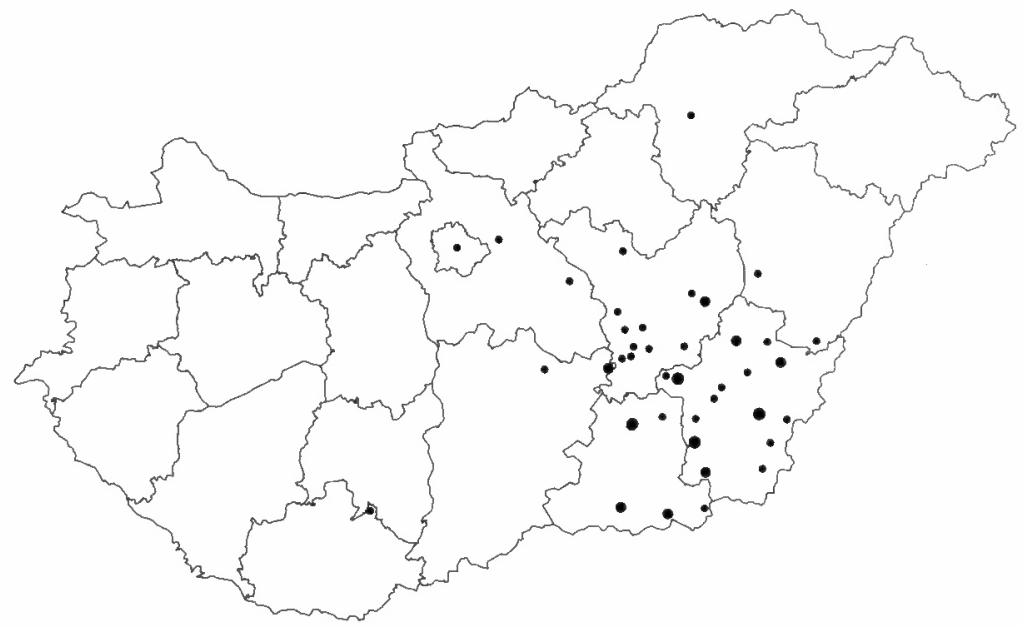

Forrás: Hallgatói kérdőívek alapján saját szerkesztés.

\section{6. ÁBRA}

A TSF-MVK nappali tagozatos hallgatóinak lakóhelye, 2006

(Residence of Full-Time Students at TSF-MVK, 2006)

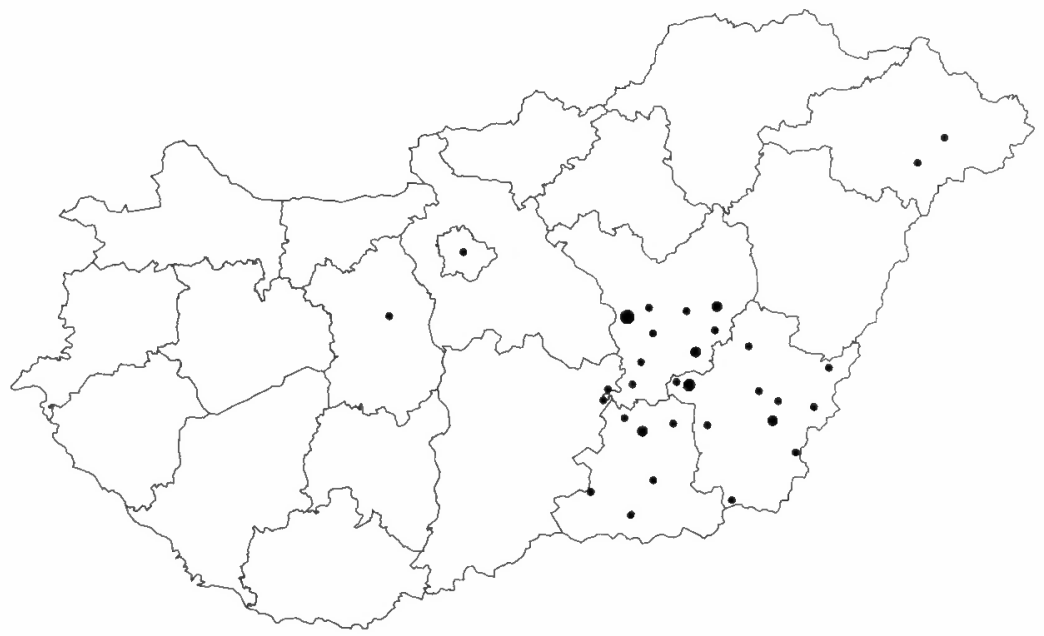

Forrás: Hallgatói kérdőivek alapján saját szerkesztés.

A szarvasi karok legfontosabb beiskolázási területe Békés megye egésze, Jász-Nagykun-Szolnok megye déli része, illetve kisebb mértékben Csongrád megye - ami lényegében megegyezik a város kơré vonható, délkelet felé kissé kitáguló, $50-60 \mathrm{~km}$ sugarú körrel. A szarvasi fơiskolákon valamivel alacsonyabb a helyben lakó diảkok aránya, mint Vásárhelyen, ám ez az utóbbi évek során folyamatosan emelkedik (5-6. ábra). 
Petrás Ede : A kisvárosi főiskolák hallgatóinak társadalmi helyzete és életmódja .

Tér és Társadalom 21. évf. 2007/4. 111-129. p.

A pedagógiai kar beiskolázási térképén még ma is észrevehetőek a kar egykor hatalmas, az Alföld egész területére kiterjedő vonzáskörének maradványai. A távolabbi beiskolázások radikális csökkenése az elmúlt évtized terméke. Egy 1995-ös vizsgálat tanúsága szerint a kilencvenes években Békésből és a szomszédos megyékből érkezett hallgatók aránya még csupán $60 \%$ körüli volt. Egy évtizeddel később ez az arány a föiskolára jelentkezők esetében meghaladta a 76\%-ot (7. ábra). A diagramon jól látható a Békés és Jász-Nagykun-Szolnok megyei hallgatók arányának gyors növekedése, és a korábban fontos beiskolázási területnek számító HajdúBihar megye, Pest megye és Budapest jelentőségének csökkenése.

A levelezỏ képzések beiskolázása a szarvasi karok esetében is valamivel szélesebb merítésú a nappalinál. Korántsem olyan széles azonban, mint a vásárhelyi levelező képzésé, mivel a pedagógiai karra csak Pest megyéböl, a mezőgazdasági karra pedig csak Budapeströl érkeztek a nappali képzésnél számottevően nagyobb arányban levelező hallgatók.

\section{7. ÁBRA}

A TSF-PFK-ra 1995-ben felvett, illetve 2005-ben jelentkezö nappali tagozatos hallgatók lakóhelye megyék szerint (\%)

(Residence of Full-Time Students at TSF-PFK by County, Those Enrolled 1995, and Candidates 2006)

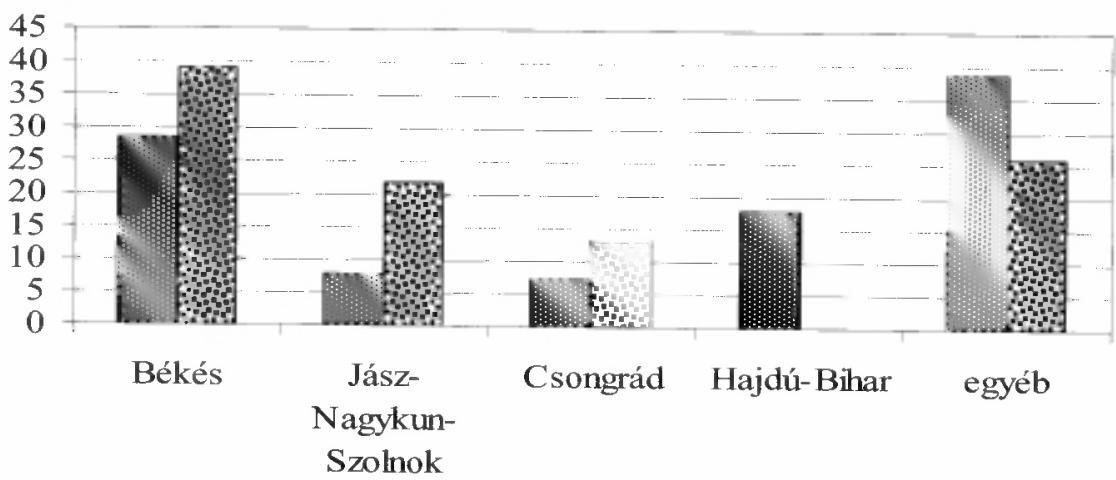

19952005

Forrás: Daróczy et al (1997), illetve Tessedik Sámuel... (2006) alapján saját szerkesztés.

A négy kar hallgatóinak lakóhelyében, illetve ennek változásában világosan megmutatkoznak a hazai felsőoktatás fejlödésének aktuális tendenciái: a diploma iránti igénynek, illetve ezzel párhuzamosan a tanulás költségeinek a növekedése következtében a fiatalok iskolaválasztási stratégiáiban felértékelödött a lakóhely és a felsőoktatási intézmény közelségének a szempontja. Ilyen körülmények között, a mobilitási esélyek egyenlósége szempontjából kiemelkedő fontosságú volna, hogy a nagy, regionális kisugárzású egyetemi központok mellett minél több kistájnak, városkörnyéknek legyen valamilyen felsőoktatási intézménye. 
Petrás Ede : A kisvárosi föiskolák hallgatóinak társadalmi helyzete és életmódja .

Tér és Társadalom 21. évf. 2007/4. 111-129. p.

TÉT XXI. évf. 2007 - 4

Gyors ténykép

119

\section{Az iskolaválasztás okai}

A karok hallgatói körében végzett kérdöíves vizsgálatunk alapján az iskolaválasztás legfontosabb motivációja a föiskolán elsajátítható szakma iránti érdeklödés. Ez természetesen nem meglepö, hiszen mind a négy föiskola valamely, többé-kevésbé lehatárolt tudományterületen képez elsősorban gyakorlati szakembereket. A második legerösebb motiváció az iskola közelsége a hallgató lakóhelyéhez, mely minden második megkérdezett hallgató számára volt fontos. Kivétel ez alól a nagykörösi kar, ahol a távolság alig befolyásolja a jelentkezők döntését.

A különbözö motivációk közötti összefüggéseket megvizsgálva kiderül, hogy akik szakmai érdeklődésböl választottak iskolát, azok számára kevésbé volt fontos a biztos felvétel reménye, illetve a más intézménybe való sikertelen jelentkezés. Egy másik jellegzetes csoportot képeznek azok, akik számára az iskola közelsége és a biztos bejutás egyaránt fontos érv volt az intézmény kiválasztásakor.

\section{8. ÁBRA}

A nappali tagozatos hallgatók intézményválasztásának motivációi

regionális összehasonlitásban, 2005-2006 (\%)

(Motivations of Full-Time Students in Their Choice of Institution, in a Regional

Comparison, 2005-2006)

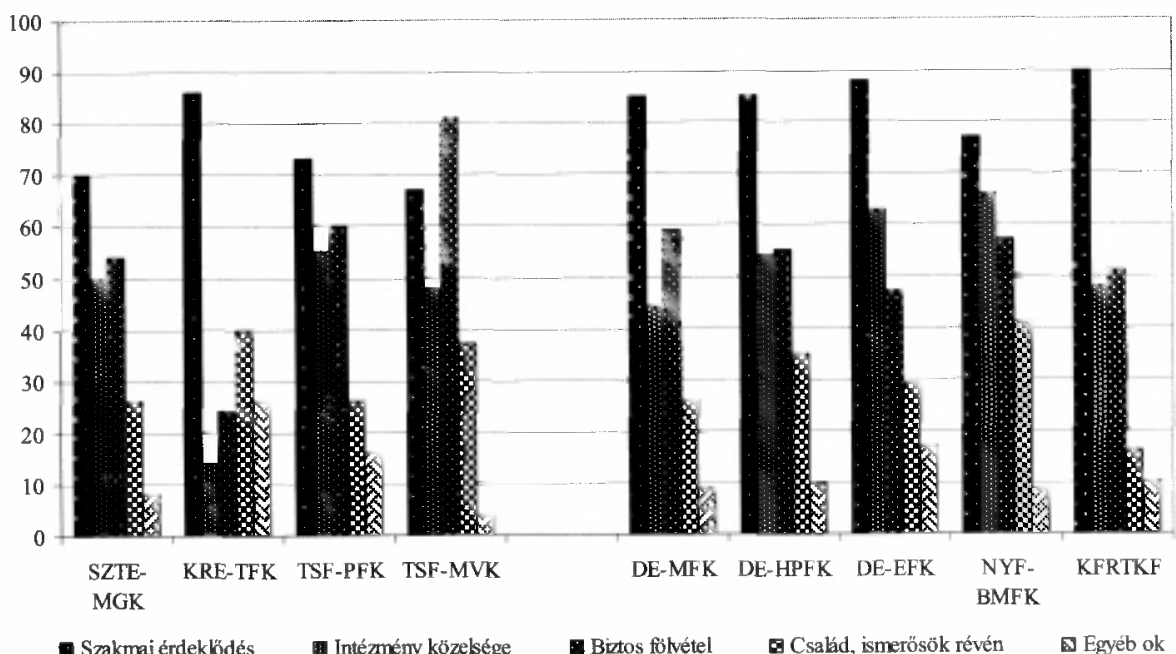

Forrás: Hallgatói kérdőívek, illetve a DE Regionális Egyetem Kutatási Program magyarországi fơiskolai kérdỏivei alapján saját szerkesztés.

A Debreceni Egyetem Regionális Egyetem Kutatási Programjának keretében 2005-ben elkészített kérdőívek felhasználásával lehetőségünk van arra, hogy a négy vizsgált kar hallgatóinak iskolaválasztási motivációit összehasonlítsuk a mintában szereplö öt észak-alföldi föiskola hasonló adataival (8. ábra). A regionális összehasonlításból kiderül, hogy a kưlönbözö intézmények hallgatóinak 
motivációi között nincsenek lényeges különbségek - azzal az apró eltéréssel, hogy az észak-alföldi föiskolákon valamivel még fontosabb a szakmai érdeklődés szerepe az iskolaválasztásban, a nyíregyházi karokon (DE-EFK és NYF-BMFK) pedig a föiskola közelsége még a dél-alföldi agrárkaroknál is hangsúlyosabb szerepet játszott a jelentkezők döntésében.

Nem csupán az összes világi föiskolától, hanem még ikerintézményétől, a debreceni református tanítóképzőtől is eltérő képletet mutat a nagykőrösi fóiskola, ahol az intézmény közelsége és a biztos felvétel szempontja jóval kisebb jelentőségü, mint a többi kar esetében, kiemelkedően fontos viszont az egyéb indokok szerepe. Ezek közül a legtöbbször a személyes elhivatást, az érzelmi alapú döntést és elhatározásuk szilárdságát említették a hallgatók. A nagykórösi diák számára a fỏiskola sajátos küldetése és keresztény értékrendje jelenti a legnagyobb vonzerôt, amelyet sok esetben családjuk vagy baráti körük is megerősít.

A szakmai érdeklődés után a szarvasi karok és a vásárhelyi föiskola hallgatóinak legfontosabb indítéka az iskola közelsége, de fontos szerepet játszik döntésükben a bejutás könnyüsége is. Ez különösen a szarvasi agráros diákokra igaz, akik számára mind az általunk vizsgált többi kar, mind az észak-alföldi fơiskolák hallgatóinál sokkal fontosabb ez a szempont.

A szarvasi pedagógusok jellegzetessége a családi indíttatás valamivel fontosabb szerepe. Ennek oka talán a város pozitiv imázsában, valamint a szarvasi óvóképzés nagy múltiában és országos jó hírében keresendö, ami alapján az itt végzett szülők, rokonok szívesen küldik gyermekeiket erre a fỏiskolára. Alátámasztja ezt a feltevést, hogy a minden hatodik pedagógus hallgató által említett egyéb okok között az óvónői hivatás és a város, illetve környezetének szépsége jelenik meg a leghangsúlyosabban.

\section{A hallgatók társadalmi helyzete}

A hallgatókkal kapcsolatos adatok talán legérdekesebb tapasztalata az, hogy mind a négy fơiskola jellegzetes, a többitöl lényegesen különböző hallgatói körrel rendelkezik.

A megkérdezett diákok szulleinek iskolai végzettségét megvizsgálva kiderül, hogy a legtöbb hallgató középvégzettségú szülök gyermeke. Ezen az egy közös ponton túl azonban már lényeges különbségek vannak az egyes karok között. A legtöbb osztályt a szarvasi agrárosok szulei végezték. A vásárhelyi szülók jellemzően középvégzettségúek, a középiskolát végzettek aránya itt jelentősen meghaladja a többi fỏiskoláét. Mindkét pedagógiai kar hallgatóinak szülei között átlagon fơlüli az általános iskolai végzettségủek aránya. A nagykőrösiek szülei között viszont a diplomások aránya is magasabb az átlagosnál, így itt jellegzetesen kétpólusú mintát kapunk (9. ábra).

E két társadalmi réteg találkozásának oka az lehet, hogy a fơiskola vallásos jellege egyaránt vonzó a református értelmiségiek, valamint a tradicionális vallásossághoz közelebb álló, alacsonyabb társadalmi státuszú rétegek számára. $\mathrm{E}$ feltevés még inkább kidomborítja a nagykörösi kar sajátos, a másik három föiskolától eltérö 
Petrás Ede : A kisvárosi főiskolák hallgatóinak társadalmi helyzete és életmódja .

Tér és Társadalom 21. évf. 2007/4. 111-129. p.

hallgatói összetételét, ami már az iskolaválasztási motivációk elemzése során is megmutatkozott. Jellemzö adat, hogy az 1998-ban felvételt nyert nappalis hallgatók több mint 70\%-a valamelyik református gimnáziumban szerzett érettségit (Jubileumi évkönyv ... 2005).

\section{9. ÁBRA}

A nappali tagozatos hallgatók szüleinek iskolai végzettsége, 2006 (\%)

(Qualification of Parents of Full-Time Stundents, 2006)

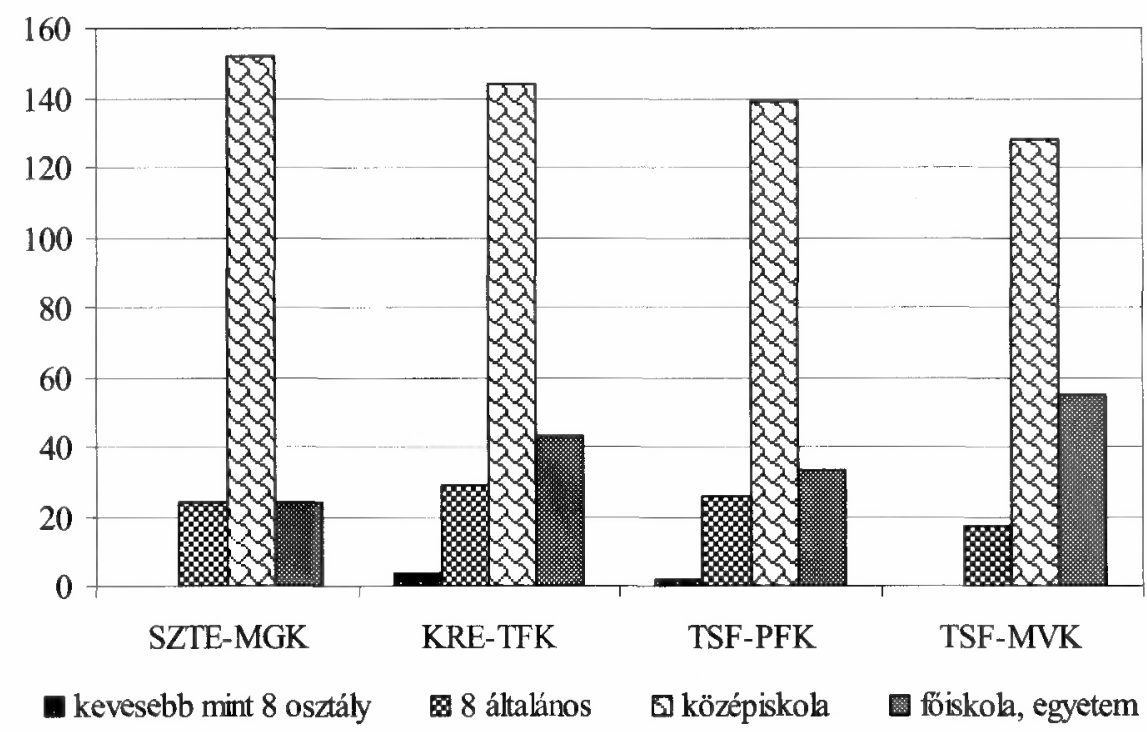

Forrás: Hallgatói kérdobivek alapján saját szerkesztés.

Ha a hallgatók lakóhelyének jellegết vesszük górcső alá, akkor megállapithatjuk, hogy a községekböl érkezők aránya a két pedagógiai karon a másik két iskolánál jóval magasabb. Vásárhelyen ezzel szemben a kisvárosi lakóhely dominál, ami az esetek többségében magát Vásárhelyt jelenti. A megyeszékhelyekröl és a fóvárosból érkezett hallgatók aránya pedig a szarvasi mezögazdasági karon a legmagasabb (10. ábra).

A vásárhelyi föiskola fontos jellemzöje, hogy - az oktatók véleménye szerint - igen magas, $50 \%$ körüli a földdel rendelkező, gazdálkodó családok gyermekeinek aránya. Ennek legfontosabb oka az lehet, hogy sokan úgy látják, a térségben a mezögazdaság még ma is húzóágazat (Kormos 2006). Figyelembe véve a helyi hallgatók magas arányát, egy másik lehetséges magyarázat a kis- és közepes méretủ helyi gazdaságok nagy száma, mely a vásárhelyi hagyományokban és - ezzel összefüggésben - a kilencvenes évek során újjászületett tradicionális birtokszerkezetben gyökerezik.

A fentieket összegezve megállapítható, hogy a vásárhelyi föiskola elsősorban a kisvárosi, mezővárosi középrétegek iskolája, a szarvasi mezögazdasági karra ezzel szemben inkább magasabb társadalmi helyzetủ hallgatók járnak. A kistelepüléseken 
Petrás Ede : A kisvárosi föiskolák hallgatóinak társadalmi helyzete és életmódja .

Tér és Társadalom 21. évf. 2007/4. 111-129. p.

lakó, alacsonyabb végzettségủ rétegek gyermekei számára pedig elsősorban a pedagógiai karok jelentenek mobilitási csatornát - bár a nagykőrösi föiskola rétegjellegénél fontosabb a felekezeti jellege.

\section{0. ÁBRA}

A nappali tagozatos hallgatók lakóhelyének megoszlása településtípus szerint, 2006 (\%) (Residence of Full-Time Students, by Type of Settlement, 2006)

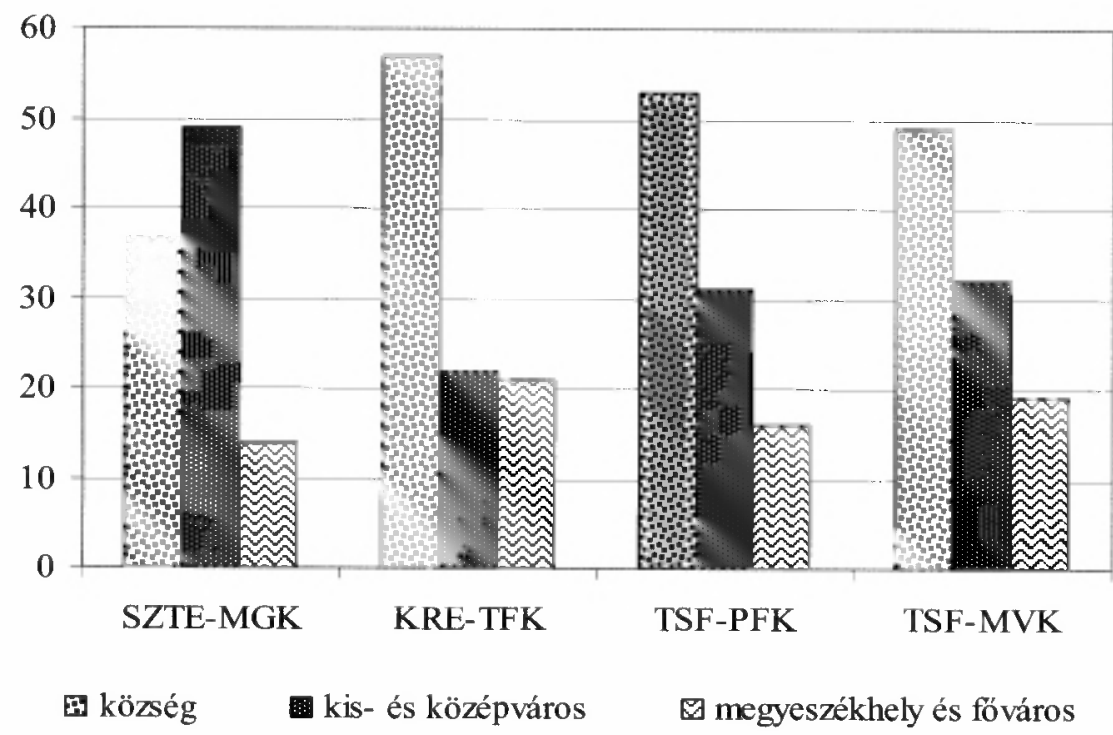

Forrás: Hallgatói kérdőívek alapján saját szerkesztés.

\section{A végzett hallgatók elhelyezkedési lehetöségei}

A két pedagógiai kar végzett hallgatóinak elhelyezkedési esélyeit elsősorban képzésük szakmai profilja befolyásolja. Mindkét csoport esetében elmondható, hogy azok sikeresek a munkaerőpiacon, akik az alapszakmájuk mellé még valamilyen speciális képzettséget is elsajátítottak.

Ebből a szempontból a nagykőrösi hallgatók vannak a legjobb helyzetben, mert ők világi szakjuk mellett egy olyan egyházi szakot is elvégeznek, amellyel bejuthatnak a református egyház intézményei által alkotott munkaerőpiacra - melynek nagysága ugyan korlátozott, ám a föiskola, illetve az egész hazai református tanítóképzés méretéhez képest komoly keresletet jelent. E csatorna müködése miatt, bár minden helyi iskolában és szociális intézményben megtalảlhatók a föiskola egykori hallgatói, mégis többségük a föiskolával együtt Nagykőröst is odahagyja.

A Szarvason végzett óvónők és tanítók elsősorban a lakóhelyükön és annak környékén keresnek munkát. A zömében községekből, kistelepülésekről érkező hallgatók elhelyezkedési esélyeit jelentősen növeli a föiskola által nyújtott sokféle specializációs lehetőség, hiszen az e területeken egyre inkább jellemzővé váló egy- 
csoportos óvodáknak és egytagozatos iskoláknak elsősorban olyan pedagógusokra van szüksége, akik az alapdiplomájuk mellett valamilyen szakirányú végzettséggel is rendelkeznek (Tessedik Sámuel... 2006).

A karon belül az óvodapedagógusoknak valamivel elönyösebb a munkaerö-piaci pozíciójuk a tanítóknál, mert míg a szarvasi tanitóképzés - országos megítélése szerint - csupán „egy a sok közül”, addig az óvóképzés országosan is magas presztízsnek, elismertségnek örvend.

Szarvason belül meglehetősen nehéz pedagógus végzettséggel munkahelyet találni, ám mégis évről évre sikerül néhány hallgatónak. Ök általában a végzettségüknek nem megfelelö munkakörben, vagy esetleg valamelyik szakirányuk segítségével tudnak elhelyezkedni - ezek közül a legkeresettebb a gyógytestnevelés, a mentálhigiéné és a fejlesztő pedagógia.

A mezőgazdasági karok hallgatói közül a vásárhelyi diákoknak valamivel jobbak az elhelyezkedési esélyeik, ami talán a két fôiskola - fentebb már taglalt - eltérő képzési stratégiájából következik. Míg a Vásárhelyen képzett mezőgazdasági vállalkozók, általános agrárszakemberek és vadgazdák számára a régió - s kisebb mértékben a város - mezőgazdasága még ma is viszonylag sok lehetöséget nyújt, addig a szarvasi karra jellemző agrár-környezetgazdálkodási képzettségek - az Európa többi részében megfigyelhető tendenciák ellenére - hazánkban mindeddig még nem jelentenek számottevő karrierlehetőséget a végzett hallgatók számára. Így feltételezhetően csupán egy töredékük talál a végzettségének megfelelő munkahelyet, jelentős részük pedig munkanélkülivé válik. Egybehangzanak e feltevéssel az oktatói interjúkban elhangzott becslések is:

„Sokan csak azért mennek el a városból, mert nem találnak itt munkahelyet. A végzösöknek $\mathrm{kb}$. a 15\%-a a szakmában helyezkedik el, $15 \%$ más szakterületen, $20 \%$ továbbtanul, a többi pedig nem talál stabil munkahelyet, vagy eleve külföldre megy." (oktatói interjú, TSF-MVK)

„Leginkább a különbözö adminisztrációkban helyezkednek el vagy továbbtanulnak egyetemen, esetleg valamilyen magáncéghez mennek, de sokan lesznek az elsỏ évben munkanélküliek." (oktatói interjú, TSF-MVK)

A vásárhelyi oktatók véleménye ennél sokkalta derülátóbb:

„Nekem meggyőzödésem, hogy a végzettek zöme az agrárpályán, ha akar, el tud helyezkedni. Én nap mint nap kapok olyan telefonokat ismerősöktöl, kollégáktól, hogy ajánljál már majd gyereket. [...] Ez inkább régión, mint városon belül müködik." (oktatói interjủ, SZTE-MGK)

„Ha valakinek van egy diplomája, szerintem sokkal küzdőképesebb. Lehet, hogy nem lesz éppen állattenyésztỏ, de itt - látva a hallgatókat öt meg tíz év múlva, meg találkozókon, ahogy jönnek - azért eléggé mögtalálják ők hál'Istennek a maguk számítását." (oktatói interjú, SZTEMGK)

A hallgatók sikeres elhelyezkedésében fontos szerepe van a kar küldetésében és légkörében is jelenlévő, farmer típusú vállalkozói szemléletnek, amit az egyik oktató eképpen fogalmazott meg:

„Itt azért célirányosan tudnak tanulmányokat folytatni, és utána újitani tudnak. Itt valahol szimatot kapnak, hogy milyen területet kell esetleg meglovagolniuk." (oktatói interjú, SZTE-MGK) 
Petrás Ede : A kisvárosi főiskolák hallgatóinak társadalmi helyzete és életmódja . Tér és Társadalom 21. évf. 2007/4. 111-129. p.

Az oktatók véleménye szerint a hallgatók egy jelentős része a városban marad, amennyiben helyben el tud helyezkedni:

„Most már az a tendencia, hogy Vásárhelyen maradnak. [...] Sokan el tudnak helyezkedni a Hód-Mezőgazdához, meg bárhová jók középvezetỏnek, mert a gyakorlatot maximálisan ismerik." (oktatói interjú, SZTE-MGK)

„Szerintem, ha lenne munka, vagy van munka, akkor marad vagy maradna a diákság Vásárhelyen." (oktatói interjú, SZTE-MGK)

Az oktatói véleményekkel egybehangzik Kis Krisztián 2005-ös felmérése, mely a megelőző öt esztendőben diplomát szerzett, Vásárhelyen és a vásárhelyi kistérségben maradt hallgatók életpályáját követte nyomon. Eredményei szerint a végzettek döntő többsége $(81 \%)$ ma a vásárhelyi kistérség határain belül lakik, és csaknem kétharmaduk rendelkezik valamilyen munkaviszonnyal. Az aktív végzettek több mint fele, az összes helyben letelepedett hallgatónak 36\%-a talált munkát az agrárszférában (Kis 2006).

\section{A hallgatók képe foiskolájukról}

Az intézményi légkör megismeréséhez az oktatók véleményén túl annak az imázsnak a feltérképezése is szükséges, amely a hallgatók fejében él az egyes fóiskolákról. A hallgatók körében végzett kérdoíves vizsgálatunk legáltalánosabb tapasztalata az, hogy mindegyik kar megítélése meglehetősen kedvező (11. ábra).

A hallgatók többsége jól érzi magát intézményében, jó hangulatúnak és családiasnak érzékeli iskoláját. Ez nem meglepő, hiszen viszonylag kis méretü, mérsékelt létszámú fơiskolákról van szó. A szarvasi agrárosok kivételével a diákok általában magasnak ítélik intézményük színvonalát. Megegyezik továbbá a hallgatók véleménye arról is, hogy a végzett hallgatók általában nem maradnak föiskolájuk városában - ami egybehangzik a kisvárosi felsőoktatási intézmények összegyüjtő és kibocsátó jellegéröl alkotott tézisünkkel.

Bár a négy kar hallgatói megítélésének számos közös pontja van, természetesen minden intézmény rendelkezik néhány sajátos, csak rá jellemző imázselemmel. Az előző két pontban tárgyalt interjús tapasztalataink ismeretében nem meglepö, hogy a nagykörösi diákok ítélik meg legkedvezöbben az intézményüket. Az ő esetükben jelenik meg a legmarkánsabban a föiskola családiassága, egyértelmủen érzékelik az intézmény fejlődését, és az elhelyezkedési lehetőségeik tekintetében is sokkal bizakodóbbak a többi hallgatói csoportnál.

Nem sokkal marad el a nagykőrösi föiskola népszerüségétől a szarvasi pedagógiai kar megítélése sem. A két kar között lényeges eltérés csak a föiskola nehézségének és elhelyezkedési esélyeiknek a megitélésében mutatkozik. A szarvasi hallgatók ugyanis kevesebb nehézséget tapasztalnak tanulmányaik során, viszont úgy érzik, hogy a végzés után nehéz lesz állást találniuk. 
Petrás Ede : A kisvárosi főiskolák hallgatóinak társadalmi helyzete és életmódja .

Tér és Társadalom 21. évf. 2007/4. 111-129. p.

TÉT XXI. évf. 2007 - 4

Gyors ténykép

\section{1. ÁBRA}

A föiskolák hallgatói megitélése szemantikus differenciálskálán, 2006

(The image of the Institutions Among Students, 2006)
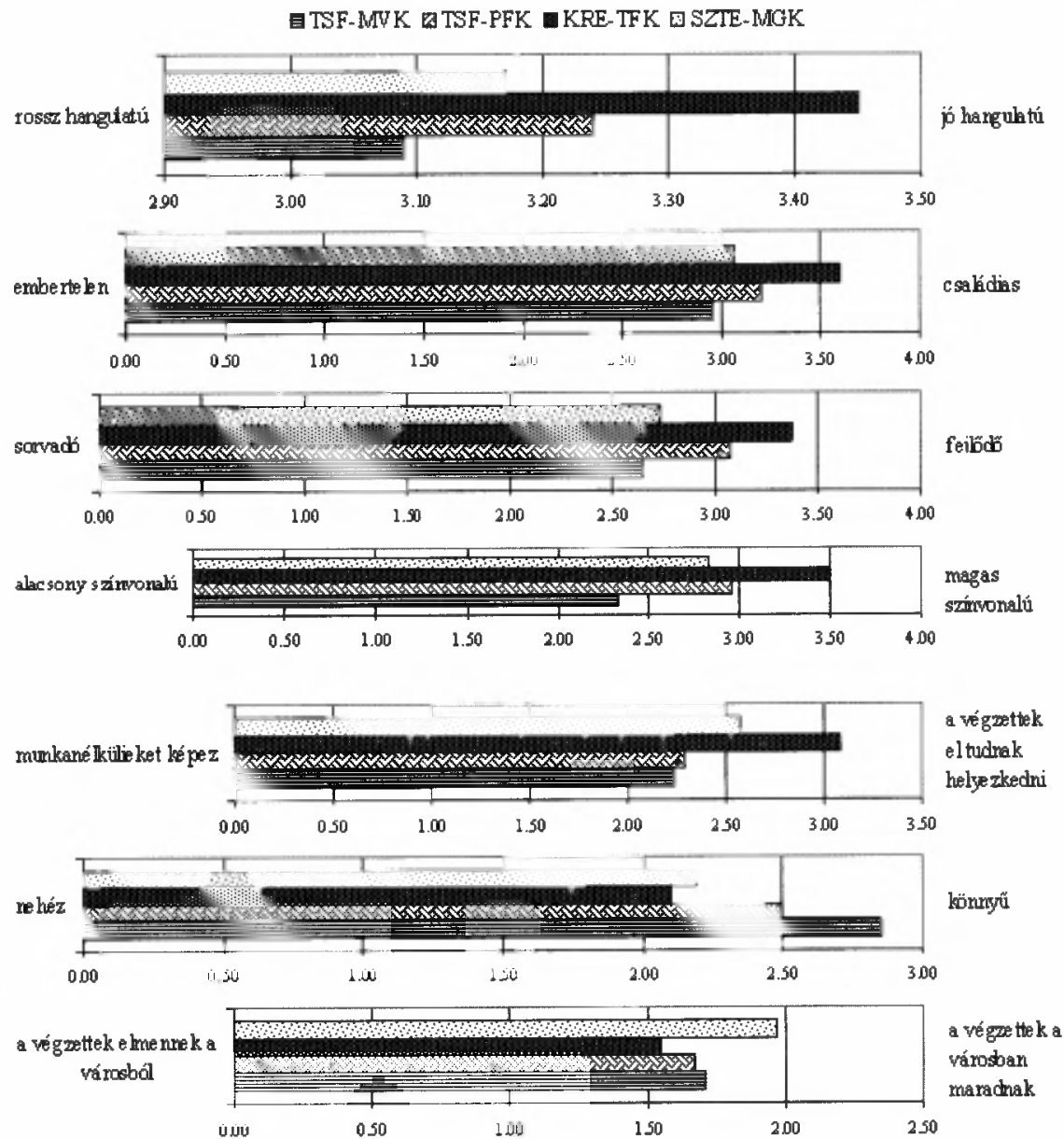

Forrás: Hallgatói kérdőivek alapján saját szerkesztés.

Aggodalmuk teljesen érthető, ha figyelembe vesszük a hazai közoktatási intézményhálózat napjainkban zajló leépülését és a pedagógus pálya presztízsének folyamatos csökkenését. Amiért a nagykőrösi hallgatók ezt nem érzékelik, az intézményük egyházi profilja, mely a munkaeröpiacnak egy sajátos, zárt szegmensét nyitja meg számukra. Ez nem túl tág ugyan, de lényegében konkurencia nélkül vesznek benne részt a föiskola végzettjei, ellentétben a világi pedagógiai karok által évröl évre kibocsátott több száz pályakezdỏ tanítóval.

A két mezőgazdasági kar diákjainak közérzetében komoly különbségek mutatkoznak. Míg a vásárhelyi föiskola megítélése nem sokkal kedvezôtlenebb a pedagógiai 
Petrás Ede : A kisvárosi föiskolák hallgatóinak társadalmi helyzete és életmódja . Tér és Társadalom 21. évf. 2007/4. 111-129. p.

karokénál, addig a szarvasi intézmény imázsában egy könnyen elvégezhetö és alacsony színvonalú iskola jelenik meg, melynek diplomája keveset ér a munkaerőpiacon.

A fentiekböl kiviláglik, hogy a szarvasi hallgatók jóval bizonytalanabbnak érzékelik jövöbeni elhelyezkedési esélyeiket. Ennek egyik oka az lehet, hogy mindkét szarvasi kar elsősorban alkalmazottakat képez cégek ill. intézmények számára ellentétben a vásárhelyi föiskolával, ahol a hallgatók jövőképében a munkahelyi elhelyezkedés mellett az önfoglalkoztatás alternatívája is megjelenik. Egy további lehetséges oka a szarvasi diákok aggodalmainak városuk periférikus fekvése. Szarvas a másik két fơiskolai városnál jóval távolabb fekszik a nagy országos centrumoktól, ami a - véglegesen még le nem telepedett - hallgatók közvetlen lehetóségeit talán nem befolyásolja, ám a városban uralkodó közhangulat révén talán jóval kedvezőtlenebb képet közvetít feléjük a munkaerőpiac országos helyzetéről.

\section{A hallgatók mindennapi élete}

A hallgatói kérdöívek legtöbb válaszadója 6-8 olyan helyet is megnevezett, amelyet gyakran látogat vagy fontosnak tart föiskolájának városában. Az így keletkezett, igen nagy elemszámú listából kilenc kategóriát hoztunk létre, amelyek megoszlása árnyalt képet ad a vizsgált intézmények hallgatóinak mindennapjairól (12. ábra).

\section{2. ÁBRA}

A hallgatók által gyakran látogatott vagy fontosnak tartott helyek kategória szerint, 2006 (\%)

(Places in Town Frequently Used by Students, by Categories, 2006)

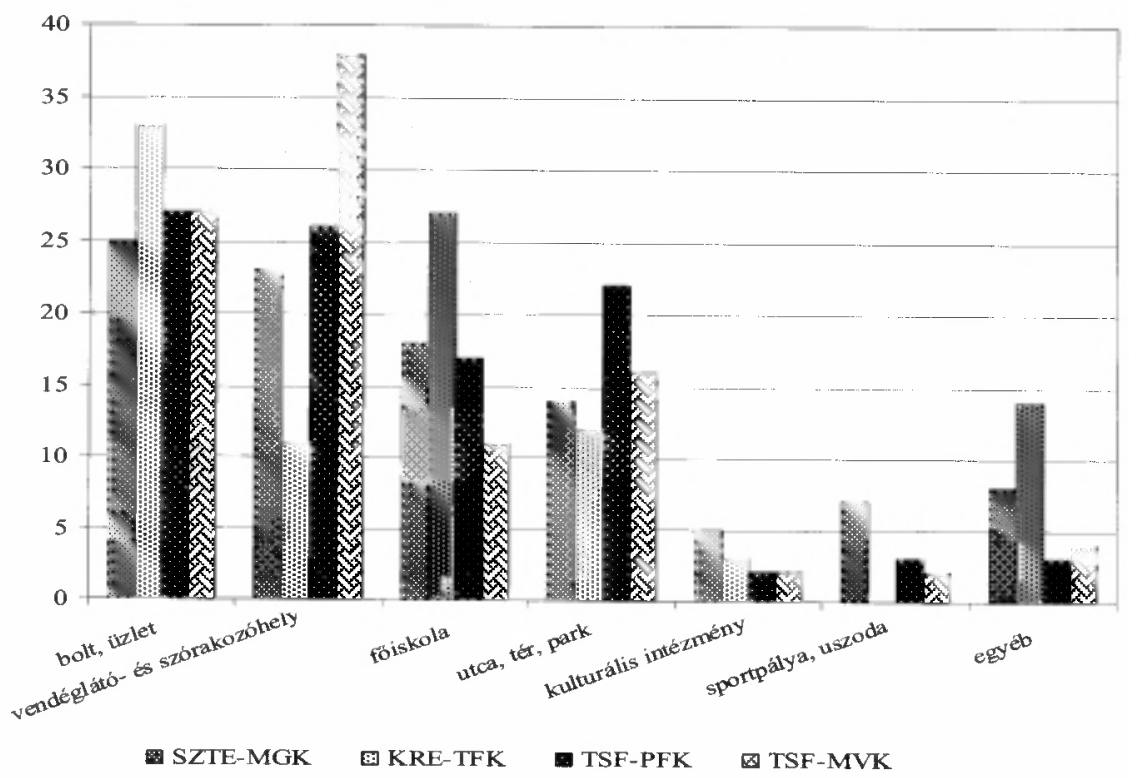

Forrás: Hallgatói kérdöivek alapján saját szerkesztés. 
Általánosságban elmondható, hogy a hallgatók a városok kínálta számos - vásárlási, müvelödési, közéleti stb. - lehetöség közül elsősorban a vásárlási, étkezési és szórakozási lehetöségeket használják ki. Ezen túl csupán egyes közterületekkel parkokkal, terekkel, néhány utcával, illetve a városok közelében fekvő kirándulóhelyekkel - állnak szorosabb kapcsolatban.

A sportolási lehetöségek kihasználása egyedül Vásárhelyen jelent meg komolyabb arányban, és itt a hallgatók kissé erősebb szálakkal kötődnek a helyi kultúrához és társadalomhoz is. Ebben nagy szerepet játszhat az, hogy ezen a karon a legmagasabb a helyi illetőségủ hallgatók aránya, akik a más településekről érkezö diákoknál már eleve sokkal több szállal kötődnek városukhoz.

A szarvasi diákok a várost szinte turistaként használják - elsősorban a boltokat, vendéglátó- és szórakozóhelyeket, köztereket, parkokat, kirándulóhelyeket látogatják. Ugyanakkor ez a vảros-központúság egyáltalán nem jelent mélyebb kapcsolatot a helyi társadalommal és kultúrával - a kérdỏíves vizsgálat eredményei szerint az erre jellemző terek itt a legkevésbé népszerüek.

Az agráros hallgatók körében az átlagosnál jóval alacsonyabb a föiskolával és tanulással kapcsolatos helyek, s valamivel magasabb a szórakozóhelyek említése ami arra utal, hogy tanulmányaik sokkal kisebb szerepet játszanak az életükben, mint a másik három kar hallgatóinál.

A két kar hallgatói között élő kapcsolat van. Számos olyan - fóiskolai és városi tér van, amelyet nap mint nap közösen használnak. Emellett a Hallgatói Önkormányzat számos közös programot, rendezvényt, kirándulást szervez számukra.

A nagykőrösiek számára ezzel szemben különösen fontos az iskola és a kollégium, valamint a templomok és az egyház szerepe, az ezen kívül eső dolgokkal pedig ők törődnek a legkevésbé. A többi intézmény hallgatóinál jóval kisebb arányban járnak vendéglátó és szórakozóhelyekre. A köztereket és parkokat jóval kisebb arányban használják, fogyasztásuk pedig szinte kizárólag a város üzleteire korlátozódik. A többi kar hallgatóihoz képest jóval nagyobb számukra a hazautazás jelentősége, amiról a távolsági közlekedés állomásainak kiemelkedő népszerüsége tanúskodik.

E zárt életmódnak az egyik oka kétségtelenül az, hogy a többségükben messzi tájról érkező, s nem csupán Nagykörösön, hanem az alföldi tájon és a mezővárosias településen is idegenül mozgó hallgatók nehezen veszik észre a városban rejlö értékeket, sőt annak egyáltalán a városiasságát. Egy másik ok a föiskola családiassága - az oktatók és hallgatók közötti bensőséges kapcsolat, a kollégisták erös közössége, a reggeli áhítatok és egyéb közös alkalmak kollektív élménye -, amely sokkal mélyebben meghatározza a hallgatók mindennapi életét mint a napjainkra jellemző töredezett helyi társadalom által nyújtható - ennél sokkal kevésbé intenzív közösségi életet élö, sekélyesebb élményeket kínáló - kisvárosi környezet.

„Mivel ök egyrészt egy gyülekezet típusú közösségben élnek, mert ez az internátus az ösi református kollégiumoknak a hagyományait is örzi, meg szellemiségét is átmenti, ha szabad azt mondani, szinte rehabilitálja, nagyon jól érzik magukat az internátusi közegben. Tehát mindent kialakitanak, mint egy kistelepülésen maguknak, tehát mini kis campus, és zömében a programjaikat házon belül szervezik. A külső kapcsolódási pontok véleményem szerint nem épültek még ki. [...] Ezt a belső, intimebb, 20-30 fös rendszeres csoportosulásokat bent élik meg a saját körükben." (oktatói interjú, KRE-TFK) 


\section{Összegzés}

A tanulmány fó tanulsága, hogy bár az empirikus mintában két-két hasonló profilủ kar szerepel, mégis mindegyik intézmény egymástól - lakóhelye, társadalmi helyzete és mindennapi élete alapjản is - jól elkülönülö hallgatói körrel rendelkezik.

A nagykőrösi tanítóképző kar a négy vizsgált intézmény közül a legkisebb. Fő profilja a tanító-hittanár ill. a diakónus-szociális munkás képzés, döntően a református egyház intézményei számára. Hallgatóinak összetétele és életmódja erősen eltér a másik három karétól, ami egyfelől a beiskolázás országos jellegében, másfelöl pedig a hallgatók átlagon felüli elhivatottságában nyilvánul meg. E különbség oka a fơiskola egyházias jellege, valamint az a kimondott intézményi stratégia, mely a napjainkban uralkodó mennyiségi szemlélettel szemben a minőségi szempontot helyezi elótérbe. A fóiskola különleges abból a szempontból is, hogy országosan egyedülálló, speciális képzést folytat - speciális beiskolázási területtel és kimeneti csatornákkal.

A hódmezővásárhelyi mezógazdasági kar szintén viszonylag kis létszámú intézmény. Hagyományos agrảrképzést folytat, elsősorban a környék kistermelői, mezỏgazdasági vállalkozói, illetve gyermekeik számára. A hallgatók többsége Vásárhelyről és környékéról érkezik. Általában erősen kötődnek az intézményhez, egy jelentös részük pedig az agrárpályához is.

A Tessedik Sámuel Fóiskola két szarvasi karának hallgatói létszáma jelentősen meghaladja a másik két intézményét. A pedagógiai kar legfontosabb, nagy hagyományú profilja az óvónỏképzés, a mezőgazdasági kar jellegadó képzési iránya pedig az agrár-környezetgazdálkodási ismeretek oktatása. A két kar diákjainak társadalmi összetétele és jövőtervei eltérnek egymástól, ám közös vonásuk a várossal való kapcsolataik kiterjedt, ugyanakkor felszínes volta - egy turista jellegü attitüd érvényesülése szarvasi tartózkodásuk ideje alatt. A szarvasi karok hallgatói érzik magukat legjobban intézményükben, ezzel szemben itt a legbizonytalanabbak jövőjükkel, végzésük utáni elhelyezkedésükkel kapcsolatban.

A két szarvasi kar hallgatóinak összehasonlítása arra enged következtetni, hogy a föiskolai városok kínálta lehetóségek leginkább a hallgatók mindennapi életét, fogyasztását és mủvelödését tudják befolyásolni, míg szakmai és letelepedési terveikre nincsenek jelentősebb hatással. A nagy egyetemi városok széles karrierkínálatával szemben a kisvárosi hallgatói stratégiákra az oktatási intézményeknek van meghatározó befolyásuk.

\section{Irodalom}

Daróczy E. et al. (szerk.) (1997) Szarvasi Óvóképzö Intézet - Brunszvik Teréz Óvóképző Főiskola évkönyve 1985-1997. Brunszvik Teréz Óvóképző Főiskola, Szarvas.

Debreceni Egyetem „Regionális Egyetem” Kutatási Program magyarországi föiskolai kérdőivei. (2005) DE Neveléstudományi Tanszék, Debrecen.

Jubileumi évkönyv 1990-2005. (2005) Károli Gáspár Református Egyetem Tanítóképző Főiskolai Kar, Nagykörös. 
Petrás Ede : A kisvárosi főiskolák hallgatóinak társadalmi helyzete és életmódja .

Tér és Társadalom 21. évf. 2007/4. 111-129. p.

TÉT XXI. évf. 2007 — 4

Kis K. (2006) Az SZTE MFK hatása a Hódmezóvásárhelyi kistérség humán eróforrásaira az ezredforduló után. - Agrár-és Vidékfejlesztési Szemle. 1. 81-87. o.

Kormos T. (2006) Kétszer annyi elsôs a vásárhelyi karon. - Dél-Magyarország. szeptember 1. http:/www.delmagyar.hu/cikk.php?id=71\&cid=131631

Tessedik Sámuel Főiskola Pedagógiai Föiskolai Kar. Oktatás-, Kutatás- és beruházásfejlesztési Koncepció. (2006) TSF-PFK, Szarvas. 